\title{
Characteristics of Children Admitted to the Emergency Department with Convulsive Epileptic Seizures: A Single-Center Study
}

\author{
Acil Servise Konvülzif Epileptik Nöbet ile Başvuran Çocukların Özellikleri: \\ Tek Merkez Çalışması
}

\author{
Emel Ataş Berksoy1, Ünsal Yılmaz2, Rana İşgüder33, Selçuk Yazıcı4, Tanju Çelik5, Aycan Ünalp2 \\ ${ }_{1}^{1}$ Tepecik Training and Research Hospital, Clinic of Pediatric Emergency, İzmir, Turkey \\ ${ }^{2}$ Behçet Uz Children's Hospital, Pediatric Clinic of Neurology, Izmir, Turkey \\ ${ }^{3}$ Behçet Uz Children's Hospital, Clinic of Pediatric Intensive Care, Izmir, Turkey \\ ${ }^{4}$ Balıkesir University Faculty of Medicine, Department of Pediatrics, Balıkesir, Turkey \\ ${ }^{5}$ Behçet Uz Children's Hospital, Clinic of Pediatric Emergency, İzmir, Turkey
}

\section{Abstract}

Introduction: To evaluate the etiology and characteristics of children admitted to the emergency department with an acute convulsive epileptic seizure.

Methods: Data of patients who were admitted to the emergency department with a convulsive epileptic seizure were reviewed. The patients were divided into febrile seizure, first idiopathic non-febrile seizure, idiopathic epilepsy, symptomatic epilepsy, and symptomatic seizure groups.

Results: A total of 335 children were included in the study. Febrile seizures were the most common cause of convulsive seizure $(38.5 \%$ of all visits), followed by idiopathic epilepsy-related seizures (35.8\%), symptomatic epilepsy-related seizures (8.1\%), first non-febrile seizures $(17.6 \%)$, and symptomatic seizures (1.5\%). The mean age of the patients was 4.73 years, and it was significantly lower in patients with febrile seizures when compared to the other groups $(p<0.001)$.

Conclusion: Knowing the characteristics of children admitted to the emergency department with a convulsive epileptic seizure is important to guide appropriate management and individualized follow-up. Keywords: Emergency department, children, epilepsy, convulsion, seizure

\section{Öz}

Amaç: Çalışmanın amacı acil servise akut konvülzif nöbet ile başvuran çocukların özelliklerini ve etiyolojisini değerlendirmektir. Yöntemler: Acil servise akut konvülzif nöbet ile başvuran hastaların dosyaları geriye dönük olarak incelendi. Hastalar febril nöbet, idiyopatik ilk afebril nöbet, idiyopatik epilepsi, semptomatik epilepsi ve semptomatik nöbet olarak gruplara ayrıldı. Bulgular: Çalışmaya toplam 335 çocuk dahil edildi. Idiyopatik epilepsi ile ilişkili nöbetler $(\% 35,8)$, semptomatik epilepsi ile ilişkili nöbetler $(\% 8,1)$, ilk ateşsiz nöbetler $(\% 17,6)$ konvülzif nöbetlerin en sık görülen nedeniydi $(\% 38,5)$ ve devamında semptomatik nöbetler $(\% 1,5)$ izledi. Hastaların ortalama yaşı 4,73 yıl iken, febril nöbet geçiren hastalarda diğer gruplara göre anlamlı olarak daha düşüktü $(p<0,001)$.

Sonuç: Acil servise konvülzif epileptik nöbet ile başvuran çocukların özelliklerinin bilinmesi, hastaların uygun yönetimi ve takipleri için önemlidir.

Anahtar Kelimeler: Acil servis, çocuk, epilepsi, konvülziyon, nöbet

\section{Introduction}

Seizures are among the most common and frightening disorders in children admitted to the pediatric emergency department. They occur in approximately $4-10 \%$ of children and account for $1 \%$ of all emergency department visits. ${ }^{1}$

Multiple disorders including febrile seizures, epilepsy, central nervous system infections, trauma, or intoxication may cause seizures in children. ${ }^{1}$ On the other hand, a number of non-

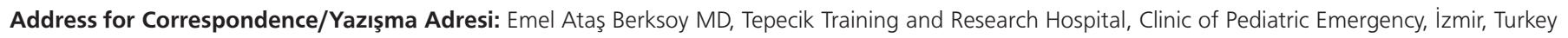
E-mail: emelberksoy@hotmail.com ORCID ID: orcid.org/0000-0002-6831-1353 Received/Geliş Tarihi: 13.03.2017 Accepted/Kabul Tarihi: 11.05.2017

${ }^{\circ}$ Copyright 2017 by Society of Pediatric Emergency and Intensive Care Medicine Journal of Pediatric Emergency and Pediatric Intensive Care published by Galenos Yayınevi. 
epileptic events including syncope, breath-holding spells, or movement disorders may mimic epileptic seizures.

In this study, we aimed to document clinical and paraclinical characteristics of children who were admitted to the pediatric emergency department with convulsive epileptic seizures.

\section{Materials and Methods}

Hospital charts of children (ranging from 1 month to 18 years) who were admitted to the pediatric emergency department at Dr. Behçet Uz Children's Hospital with convulsive epileptic seizures from January 01, 2013 to December 31, 2013 were retrospectively reviewed. Only the data on the last visit were included in the study for patients who were admitted to the emergency department more than one time during the study period. Patients with non-convulsive seizures, non-epileptic events including syncope, breath holding spells, movement disorders, or psychogenic events were excluded from the study. The study was approved by the institutional Ethics Committee. The seizures were classified as generalized tonicclonic and partial seizures according to the Commission on Epidemiology and Prognosis and the International League Against Epilepsy. ${ }^{2}$ Status epilepticus was defined as "a single epileptic seizure of more than 30 minutes or repeated epileptic seizures where consciousness was not regained between ictal events in a period of more than 30 minutes". 2

The patients were divided into febrile seizure, first idiopathic non-febrile seizure, idiopathic epilepsy-related seizure, symptomatic epilepsy-related seizure, and symptomatic seizure groups.

A febrile seizure was defined as: 1) an epileptic convulsion that occurred in childhood between 6 months and five years of age; 2 ) associated with a fever greater than $38{ }^{\circ} \mathrm{C}$; and 3) without previous neonatal seizure and intracranial infection or previous unprovoked seizure. ${ }^{3}$ Simple febrile seizures were classified either by generalization, lasted less than 15 minutes, and/or occurred once during a 24-hour period. On the other hand, they were classified as complex febrile seizures when they lasted more than 15 minutes, had focal features at any time, and/or recurred within a 24-hour period. ${ }^{4}$

First, the non-febrile seizure was defined as an unprovoked seizure in children who had not experienced any seizure previously other than febrile seizures. If the probability was increased for further seizures, epilepsy diagnosis was made in patients with a first afebrile seizure. This was similar to the general recurrence risk (at least 60\%) after two unprovoked seizures.

An epilepsy-related seizure was defined as; 1) a convulsive epileptic seizure that was not symptomatic; 2 ) occurring in a child with a previous diagnosis of idiopathic epilepsy; 3) when the seizure was the second unprovoked seizure; 4) leading to the diagnosis of idiopathic epilepsy; or 5) one unprovoked seizure and an evidence for the probability of further seizures similar to the general recurrence risk (at least $60 \%$ ) after two unprovoked seizures. ${ }^{5}$

Symptomatic epilepsy was defined as; 1 ) an epilepsy of an acquired or genetic cause; 2) associated with gross anatomic abnormalities and/or clinical features; and 3) indicative of underlying disease or condition, such as developmental and congenital disorders associated with cerebral pathologic changes (whether genetic or acquired in origin). Idiopathic epilepsy was defined as an epilepsy of presumed and predominately genetic or genetic origin. This type generally has no gross neuroanatomic abnormality such as epilepsies with presumed multigenic or complex inheritance. ${ }^{6}$ An acute symptomatic seizure was defined as a convulsive epileptic seizure in a normal child with no neurological history within 1 week from an identified acute neurologic insult.

The data including age, gender, prior history of seizures, seizure characteristics, neurologic examination findings, electroencephalography (EEG), neuroimaging findings, seizure management, and short-term outcome (discharge/admission/ intensive care referral/death) were compared between the seizure groups.

\section{Statistical Analysis}

The data were analyzed using SPSS for Windows software package, version 20.0 (SPSS, Chicago, IL). Continuous variables were expressed as mean \pm standard deviation or interquartile range. Pearson's chi-square test or Fisher's exact test was used where appropriate for analysis of betweengroup differences in discrete variables. A p-value of less than 0.05 was considered statistically significant.

\section{Results}

A total of 335 children (177 boys and 158 girls) presented to the emergency department with an attack of convulsive epileptic seizures during the 12-month period and were enrolled in the study. During the study period, the number of visits to the emergency department was 118.518. Therefore, $0.28 \%$ of all visits for the 12 -month study period were due to seizure disorders.

Overall, febrile seizures were the most common cause of convulsive seizure (38.5\% of all visits), followed by idiopathic epilepsy-related seizures (35.8\% of all visits), symptomatic epilepsy-related seizures (8.1\% of all visits), first non-febrile seizures (17.6\% of all visits), and symptomatic seizures (1.5\% of all visits). Among the 129 patients with febrile seizures, 
93 (72.1\%) had simple, and 36 (27.9\%) had complex febrile seizures (Table 1).

The etiologies of epilepsy in the symptomatic epilepsy group were perinatal events in 17 patients, cerebral malformation in four patients, neurodegenerative disorders in four patients, and neurofibromatosis and posttraumatic epilepsy in one patient each. The causes of seizures in patients with symptomatic seizures were intracranial hemorrhage in three patients and encephalitis and meningitis in one patient each (Table 1).

The mean age of the patients was 4.73 years, which was significantly lower in patients with febrile seizures compared to the other groups $(p<0.001)$. Generalized tonic-clonic seizure was the most common seizure type ( $n=300 ; 90.9 \%)$, and it was significantly more common in patients with febrile seizures ( $p=0.043$ ).

An infection was identified in all patients with febrile seizures, including $24 \%$ of patients with first non-febrile seizure, $21 \%$ of patients with idiopathic epilepsy, and $7 \%$ of patients with symptomatic epilepsy $(p<0.001)$. Overall, $26(7.8 \%)$ children had a prior neurodevelopmental disorder such as cerebral palsy or cerebral malformations. Prior neurologic abnormalities were identified in all patients within the symptomatic epilepsy group, however, none were identified in the other groups.

EEG was performed in 167 of the 330 patients. Among these children, the rate of EEG abnormalities was significantly lower in patients with febrile seizures when compared to the other groups ( $p<0.001)$ (Table 2, 3).

Neuroimaging studies that were obtained in $43.9 \%$ of patients revealed abnormalities, in $13.3 \%$ of patients with first non-febrile seizures, $20.2 \%$ of patients with

Table 1. Etiologic distribution of patients admitted to the emergency department with a convulsive epileptic seizure

\begin{tabular}{ll|}
\hline Etiology & Number, (\%) \\
Febrile seizure & $129(38.5)$ \\
Simple & $93(27.8)$ \\
Complicated & $36(10.7)$ \\
First afebrile seizure & $59(17.6)$ \\
Idiopathic & $54(16.1)$ \\
Seizure due to acute neurologic pathology & $5(1.5)$ \\
Intracranial hemorrhage & $3(0.9)$ \\
Encephalitis & $1(0.3)$ \\
Meningitis & $1(0.3)$ \\
Epilepsy & $147(43.9)$ \\
Idiopathic epilepsy & $120(35.8)$ \\
Symptomatic epilepsy & $27(8.1)$ \\
Perinatal events & $17(5.1)$ \\
Cerebral malformation & $4(1.2)$ \\
Neurodegenerative disorders & $4(1.2)$ \\
Neurofibromatosis & $1(0.3)$ \\
Posttraumatic epilepsy & $1(0.3)$ \\
\hline
\end{tabular}

idiopathic epilepsy, $45.5 \%$ of patients with symptomatic epilepsy, and was not determined in patients with febrile seizures $(p<0.001)$. Fourteen $(9.5 \%)$ patients had cerebral magnetic resonance imaging (MRI) abnormalities relevant to seizure disorders, including cerebral malformations in four $(1.2 \%)$, potential neurodegenerative disorders in four $(2.7 \%)$, intracranial hemorrhage in three $(2.0 \%)$ patients, and potential encephalitis and posttraumatic epilepsy in one $(0.7 \%)$ patient each. Abnormal results of physical and neurological examinations found in all 14 of these children were encephalopathic or focal motor deficient (Table 2, 3).

A family history of epilepsy was determined in $16 \%$ of patients with non-febrile seizures, in $12 \%$ of patients with idiopathic

\begin{tabular}{|c|c|}
\hline Parameter & Number \pm SD, $(\%)$ \\
\hline Number & 335 \\
\hline Mean age at admission, years & $\begin{array}{l}4.73 \pm 4.07 \\
\text { ( } 2 \text { month-17 years) } \\
\text { (median 3) }\end{array}$ \\
\hline \multicolumn{2}{|l|}{ Sex } \\
\hline Female & $158(47.2)$ \\
\hline Male & $177(52.8)$ \\
\hline Infection at admission & $175(52.2)$ \\
\hline Upper respiratory infection & $159(47.5)$ \\
\hline Lower respiratory infection & $7(2.1)$ \\
\hline Acute gastroenteritis & $8(2.4)$ \\
\hline Acure urinary tract infection & $1(0.3)$ \\
\hline \multicolumn{2}{|l|}{ Seizure type } \\
\hline Generalized & $304(90.7)$ \\
\hline Focal & $31(9.3)$ \\
\hline Acute anticonvulsant treatment & $109(32.5)$ \\
\hline Rectal/i.v. diazepam & $48(14.3)$ \\
\hline i.v. midazolam & $19(5.7)$ \\
\hline Multiple & $42(12.5)$ \\
\hline Prior neurologic abnormalities & $26(7.8)$ \\
\hline \multicolumn{2}{|l|}{ Outcome } \\
\hline Discharged & $289(86.3)$ \\
\hline Referral to intensive care unit & $43(12.8)$ \\
\hline Death & $3(0.9)$ \\
\hline Abnormal interictal EEG & $115 / 168(68.5)$ \\
\hline Status epilepticus & $19(5.7)$ \\
\hline $\begin{array}{l}\text { Patients underwent neuroimaging, } \\
\text { MRI }(n=106), C T(n=14) \text {, TF USG }(n=24)\end{array}$ & $147(43.9)$ \\
\hline Normal & $113(76.9)$ \\
\hline Abnormal findings irrelevant to diagnosis & $20(13.6)$ \\
\hline Abnormal findings relevant to diagnosis & $14(9.5)$ \\
\hline
\end{tabular}


epilepsy, in 7\% of patients with febrile seizures, and was not determined in patients with symptomatic epilepsy. The rate of family history of febrile seizures was significantly higher in the febrile seizure group when compared to the other groups $(p<0.001)$ (Table 3$)$. Acute anti-convulsant drugs were administered to control seizures in 106 (32.1\%) patients in the emergency department. In $94.5 \%$ of them, seizures were resolved with the first or second line of anti-epileptic drugs (two doses of benzodiazepines and phenytoin). The overall rate of status epilepticus was not high and ranged from 3.7\% to $6.7 \%$ among the groups (Table 2).
After emergency management in the emergency department, $286(86.6 \%)$ patients were discharged, 41 (12.4\%) were referred to the intensive care unit, and three (1\%) patients died. The percentage of patients who were referred to the intensive care unit was highest in the idiopathic epilepsy group $(21.7 \%)$. Two patients in the first non-febrile seizure group and one in idiopathic epilepsy group died, however, no death was observed in other groups (Table 2, 3). Interestingly, all the children who died were pre-diagnosed with inborn errors of metabolism. The cause of death in the emergency department was severe metabolic acidosis-related cardiac arrest in these children.

Table 3. Comparisons of demographic and clinical data of patients admitted to emergency department with convulsive epileptic seizure

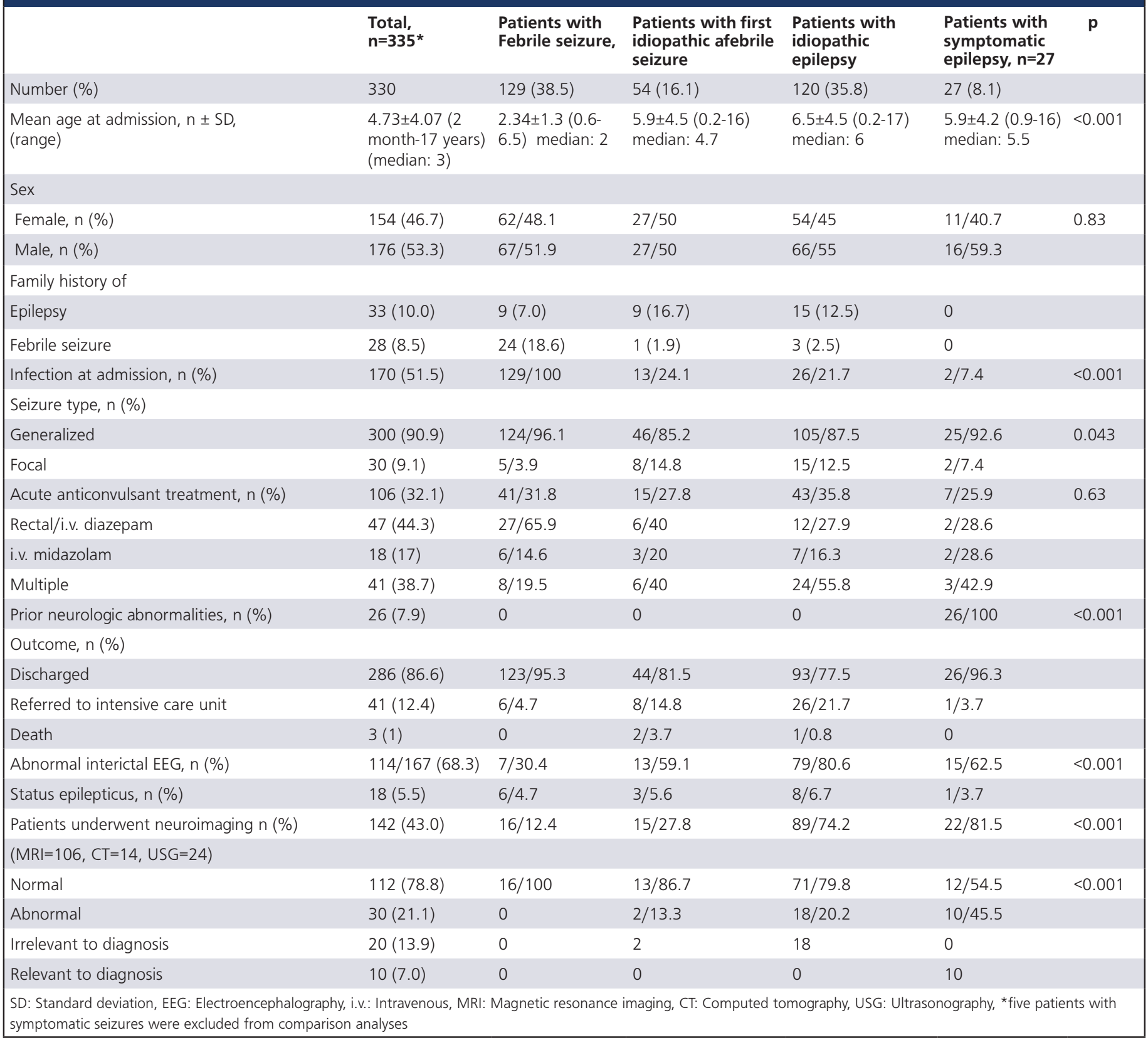




\section{Discussion}

In this report, we conducted an exploratory study to characterize children who were admitted to the pediatric emergency department for convulsive epileptic seizures. Previous studies reported that seizures accounted for approximately $1-2 \%$ of all pediatric emergency department visits. ${ }^{7-11}$ In our study, only $0.28 \%$ of all emergency department visits were due to a convulsive epileptic seizure. The very low incidence of seizures among all pediatric emergency department visits may be due to the fact that emergency departments in Turkey have become a common place for both urgent and non-urgent child healthcare provision. During 2013, the total number of emergency department visits was 87 million. This number of admittance was higher than the total population of Turkey. ${ }^{12}$

Similar to previous reports, febrile seizures were the first most frequent cause of convulsive epileptic seizures in patients admitted to the emergency department during the study period. 9,10,13,14 It has been previously reported that about $10-40 \%$ of children with febrile seizures had a family history. ${ }^{14-16}$ In our series, a family history of febrile seizures was obtained in $18.6 \%$ of children with these same seizures, which was significantly higher than those in other groups. This may suggest that emergency physicians should consider a diagnosis of febrile seizure when a child presents with a seizure and/or has a family history of febrile seizures.

The incidence of first non-febrile seizures in our study was $17.6 \%$, which was lower than a previously reported rate of $29 \% .{ }^{14}$ In our series, the percentage of acute neurologic insult (i.e., cerebral hemorrhage as a cause of seizure) was $1.5 \%$. This was consistent with the previously reported rate of $2 \% \cdot{ }^{10}$ Although it has been demonstrated that only a minority of children who presented with a seizure had an acute neurologic insult, a high index of suspicion must be maintained in order to adequately manage and diagnose the proper cerebral disorder.

Neuroimaging studies are not recommended in children presenting with a simple febrile seizure. ${ }^{17}$ Even for children with first complex febrile seizures, the risk of intracranial pathologic conditions that require emergency neurosurgical or medical intervention is low. This suggests that routine emergency neuroimaging for this population is unnecessary. ${ }^{18}$ Interestingly, no patient presenting with febrile seizures had neuroimaging abnormalities in our series, which is consistent with these reports. However, clear evidence-based guidelines regarding complex febrile seizures are lacking. Therefore, clinical findings remain the most important tool for identifying children with complex febrile seizures who are candidates for neuroimaging evaluation. ${ }^{19}$ Currently, MRI studies are considered to be the method of choice for an accurate diagnosis after a first non-febrile seizure presentation..$^{20}$ In our series, neuroimaging investigations revealed abnormalities in $13.3 \%$ of patients with first non-febrile seizures, in $20.2 \%$ of patients with idiopathic epilepsy-related seizure, and $45.5 \%$ of patients with symptomatic epilepsy-related seizure. However, only 14 patients with neuroimaging abnormalities were relevant to seizures. Similarly, 13 (4.1\%) of the 319 children who underwent imaging for a first episode of nonfebrile seizure with focal manifestations were found, in a previous study, to have clinically urgent intracranial pathology resulting in a change of initial patient management. ${ }^{21}$ In another report on 319 patients who were admitted to the emergency department with a first attack of seizure, 61 underwent neuroimaging studies and 16 patients were found to have abnormal imaging findings. ${ }^{14}$ Fourteen of these 16 patients showed abnormal brain imaging results and were predicted from their clinical histories as well as the physical and neurological examinations. ${ }^{14}$ Thus, it can be suggested that emergent brain imaging studies should not be routinely performed in children who present with a seizure and have no known history of head injury, have normal physical and neurological examinations, and/or no acute symptomatic cause other than fever.

It has been reported that EEG's performed for new-onset seizures show epileptiform discharge in approximately $18 \%$ to $56 \%$ of children. ${ }^{22}$ More than half of the children presented with a seizure had epileptiform discharges in our series, except for the patients with febrile seizures. Thus, EEG should be considered in the diagnostic evaluation of patients presenting with non-febrile seizures.

Benzodiazepines are the anti-convulsant drugs of choice for the management of an acute seizure. When seizure activity persists despite repeated doses of benzodiazepines, intravenous phenytoin is recommended. In our series, seizures were stopped in approximately two-thirds of patients before they arrived at the emergency department. Of the remaining one-third, 18 patients did not respond to benzodiazepines and phenytoin administration, and required midazolam and/ or thiopental coma in the intensive care unit. In a previous study, it was reported that $5 \%$ of seizures were still ongoing upon arrival to the emergency department. ${ }^{10}$ In another study, $5 \%$ of all children who presented with a seizure were diagnosed with status epilepticus. ${ }^{9}$ Although the majority of the seizures stopped before arrival to the emergency department, it was imperative to administer the appropriate anti-convulsant medication and arrange intensive care referral in case of status epilepticus.

\section{Study Limitations}

The main limitation of the study is its retrospective design. In addition, MRI's with abnormal findings were not re-reviewed by the radiologists for the study purpose. 


\section{Conclusion}

Febrile seizures are the most common in children admitted to the emergency department with a convulsive seizure. We show that a seizure may be an initial manifestation of a wide variety of disorders, including serious acute cerebral insults. Knowing the characteristics of children admitted to the emergency department with a convulsive epileptic seizure is important to guide appropriate management and individualized follow-up.

\section{Ethics}

Ethics Committee Approval: The study was approved by the institutional Ethics Committee.

Informed Consent: The use of the patient's datas was approved by the hospital management.

Peer-review: Externally and Internally peer-reviewed.

\section{Authorship Contributions}

Surgical and Medical Practices: E.A.B., Ü.Y., R.I., T.Ç., A.Ü., Concept: E.A.B., Ü.Y., Design: E.A.B., Ü.Y., Data Collection or Processing: E.A.B., Analysis or Interpretation: Ü.Y., R.I., S.Y., Literature Search: S.Y., E.A.B., Writing: E.A.B.

Conflict of Interest: No conflict of interest was declared by the authors.

Financial Disclosure: The authors declared that this study recieved no financial support.

\section{References}

1. Friedman MJ, Sharieff GQ. Seizures in children. Pediatr Clin North Am. 2006;3:257-77.

2. No authors listed. Guidelines for epidemiologic studies on epilepsy. Commission on Epidemiology and Prognosis, International League Against Epilepsy. Epilepsia. 1993;34:592-6.

3. Amir A Kimia, Vincent W. Chiang. Seizures. In: Kathy N. Shaw, Richard G. Bachur (eds). Texbook of Pediatric Emergency Medicine. 7th ed. Philadelphia, Wolters Kluwer; 2016:465-71.

4. No authors listed. Practice parameter: the neurodiagnostic evaluation of the child with a first simple febrile seizure. American Academy of Pediatrics. Provisional Committee on Quality Improvement, Subcommittee on Febrile Seizures. Pediatrics. 1996;97:769-72.

5. Fisher RS, Acevedo C, Arzimanoglou A, Bogacz A, Cross JH, et al. ILAE official report: a practical clinical definition of epilepsy. Epilepsia. 2014;55:475-82.
6. Shorvon SD. The etiologic classification of epilepsy. Epilepsia. 2011;52:1052-7

7. Martindale JL, Goldstein JN, Pallin DJ. Emergency Department Seizure Epidemiology. Emerg Med Clin North Am. 2011;29:15-27.

8. Ouellette E, Chong J, Drake K, Labiner DM. Emergency department care of seizure patients: demographic trends in southern Arizona. Epilepsy Behav. 2011;21:382-6.

9. Smith RA, Martland T, Lowry MF. Children with seizures presenting to accident and emergency. J Accid Emerg Med. 1996;13:54-8.

10. Bergamo S, Parata F, Nosadini M, Boniver C, Toldo I, et al. Children with convulsive epileptic seizures presenting to Padua pediatric emergency department: The first retrospective population-based descriptive study in an Italian health district. J Child Neurol. 2015;30:289-95

11. Pallin DJ, Goldstein JN, Moussally JS, Pelletier AJ, Green AR, et al. Seizure visits in US emergency departments: epidemiology and potential disparities in care. Int J Emerg Med. 2008;1:97-105.

12. Ministry of Health of Turkey Republic. Public Hospital Statiscal Year book. 2014.

13. Leung AK, Robson WL. Febrile seizures. J Pediatr Health Care. 2007;21:250-5.

14. Chen $C Y$, Chang YJ, Wu HP. New-onset seizures in pediatric emergency. Pediatr Neonatol. 2010;51:103-11.

15. Wolf SM, Ochoa JG, Conway EE Jr. Seizure management in pediatric patients for the nineties. Pediatr Ann. 1998;27:653-64.

16. Chung B, Wat LC, Wong V. Febrile seizures in southern Chinese children: incidence and recurrence. Pediatr Neurol. 2006;34:121-6.

17. Duffner PK, Berman PH, Baumann RJ, Fisher PG, Green JL, et al. Febrile Seizures: Guideline for the Neurodiagnostic Evaluation of the Child With a Simple Febrile Seizure. Am Acad Pediatr. 2011;127:389-94.

18. Teng D, Dayan P, Tyler S, Hauser WA, Chan S, et al. Risk of intracranial pathologic conditions requiring emergency intervention after a first complex febrile seizure episode among children. Pediatrics. 2006;117:304-8.

19. Kimia AA, Bachur RG, Torres A, Harper MB. Febrile seizures: emergency medicine perspective. Curr Opin Pediatr. 2015;27:2927.

20. Pohlmann-Eden $B$, Newton M. First seizure: EEG and neuroimaging following an epileptic seizure. Epilepsia. 2008;49(Suppl 1):19-25.

21. Aprahamian N, Harper MB, Prabhu SP, Monuteaux MC, Sadiq Z, et al. Pediatric first time non-febrile seizure with focal manifestations: Is emergent imaging indicated? Seizure. 2014;23:740-5.

22. Wirrell EC. Prognostic significance of interictal epileptiform discharges in newly diagnosed seizure disorders. J Clin Neurophysiol. 2010;27:239-48 